九州大学学術情報リポジトリ

Kyushu University Institutional Repository

\title{
Effects of Bulb Storage Temperature and Darkness on Stem Elongation in Tulip
}

Okubo, Hiroshi

Laboratory of Horticultural Science, Faculty of Agriculture, Kyushu University

Uemoto, Shunpei

Laboratory of Horticultural Science, Faculty of Agriculture, Kyushu University

https://doi.org/10.5109/23946

出版情報 : 九州大学大学院農学研究院紀要. 35 (1/2)，pp.27-33，1990-12. Kyushu University バージョン：

権利関係 : 
J. Fac. Agr., Kyushu Univ., 35 (1-2), $27-33$ (1990)

\title{
Effects of Bulb Storage Temperature and Darkness on Stem Elongation in Tulip
}

\author{
Hiroshi Okubo and Shunpei Uemoto* \\ Laboratory of Horticultural Science, Faculty of Agriculture, \\ Kyushu University 46-01, Fukuoka 812, Japan \\ (Received June 15,1990)
}

\begin{abstract}
Growth of non-cold-treated tulip bulbs of cv. Paul Richter at $20^{\circ} \mathrm{C}$ was retarded and the final length of the flower stalks was reduced under natural light, whereas the reduction in elongation of them was less in the dark. Elongation of the last internode of non-coldtreated tulips was more promoted than that of the first internode in the dark. Length of the last internode of cold-treated tulips in the dark was almost the same as that in the light when the dark-grown plants had received the light at their early growth stage. Dark treatment after flowering of the cold-treated plants in the light was promotive on elongation of the last internode but not on the first internode elongation. Partial substitution for cold requirement by dark, and promotive effect of dark treatment on the elongation of the last internode as well as that of the first internode within limited conditions were suggested.
\end{abstract}

\section{INTRODUCTION}

Bulbs of tulip require a specific period of low temperature after the completion of flower differentiation for rapid growth and flowering after planting. High storage and growth temperatures retard the growth and reduce the final length of the flower stalk (Rees, 1969 ; van Bragt and Zijlstra, 1971; Moe and Wickstrøm, 1973, 1979). Increasing duration of low temperature storage of tulip bulbs increased stem length, with the last internode being affected as well as the first internode, and the prolonged storage enhanced a proportionally greater increase in the length of the first internode compared with the last internode (Charles-Edwards and Rees, 1975).

Continuous dark at $20^{\circ} \mathrm{C}$ stimulated lower internode elongation of cold-treated tulip flower stalk and inhibited the elongation of upper internodes, while the greatest elongation occurred in the last internode under natural light (Okubo and Uemoto, 1984).

In this study, effects of storage temperature and darkness on stem elongation were investigated.

\section{MATERIALS AND METHODS}

Tulip bulbs (Tulipa gesneriana L. cv. Paul Richter), 11-12 cm circumference, were harvested in Tottori Prefecture. Upon arrival at the laboratory in July, they were stored at $25^{\circ} \mathrm{C}$ in dark until used. One group of the bulbs was dry-stored at $5^{\circ} \mathrm{C}$ from September 21 to November 9 following the treatment at $15^{\circ} \mathrm{C}$ for 20 days from September 1 (cold-treated bulbs), and another group was dry-stored at $20^{\circ} \mathrm{C}$ continu-

\footnotetext{
* Present address; Oita Junior College, Oita 870
} 
ously from September 1 to November 9 (non-cold-treated bulbs). On November 10, after removal of the tunics, they were planted in wooden boxes $(45 \mathrm{~cm} \times 22 \mathrm{~cm})$ which contained a medium of sand $10 \mathrm{~cm}$ deep, and grown at $20^{\circ} \mathrm{C}$ under natural light in the phytotron or in the dark at Biotron Institute, Kyushu University. Some of the cold-treated bulbs grown in the light were transferred to the dark, and those grown in the dark were transferred to the light on December 6 or on flowering day (December 26).

Shoot lengths at 5 day intervals and the internode lengths at or five days after flowering were recorded. The flowering date was taken when the outside of the perianth was in fully colored or when flower growth ceased. A pale green safety lamp was used when measuring the shoot length, sampling or watering the dark-grown tulips to avoid the influence of light. Otherwise, total darkness was maintained throughout the dark treatment.

\section{RESULTS}

Cold-treated tulips grown under both natural light and the dark showed more rapid shoot elongation and earlier flowering than non-cold-treated tulips (Fig. 1). Lightgrown tulips reached anthesis earlier than dark-grown tulips and the plant height of the former was less than the latter. Differences in the shoot length and the number

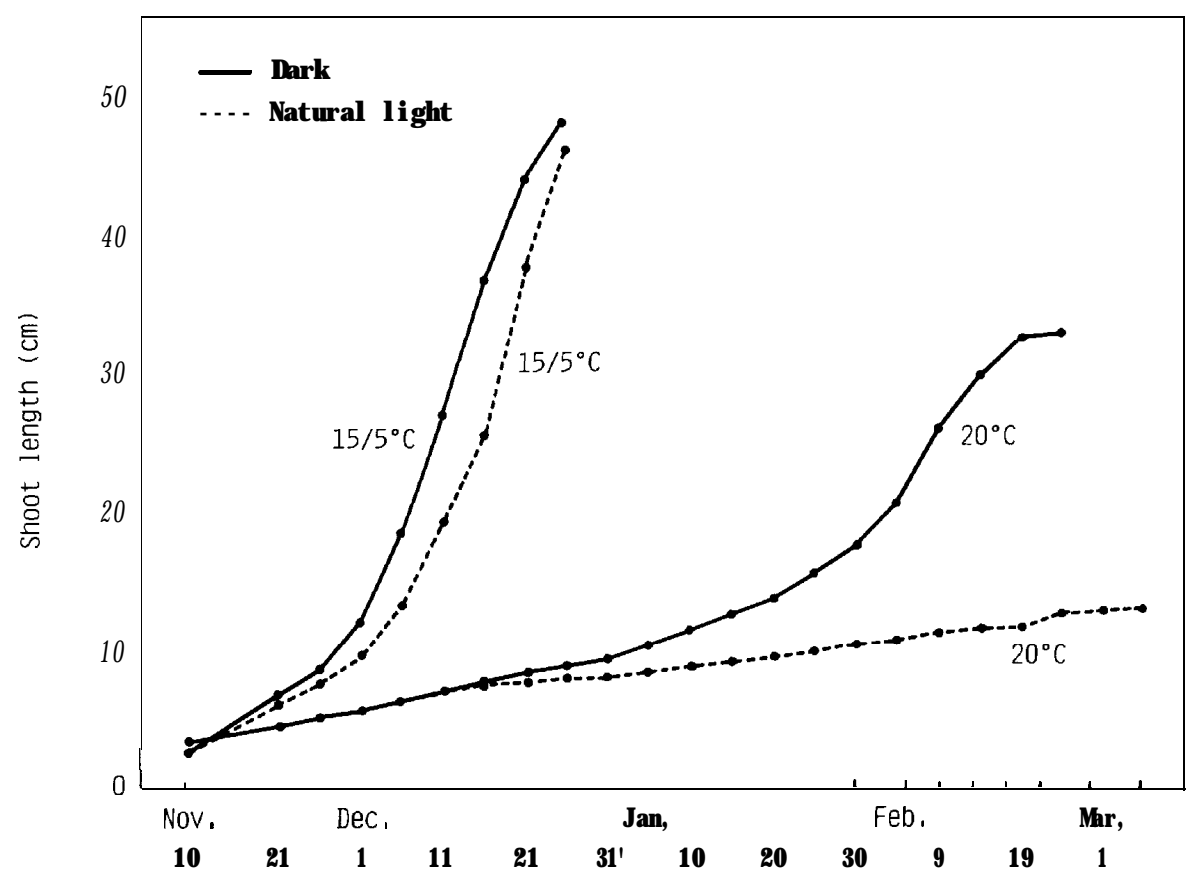

Fig. 1. Effects of bulb storage temperatures and light conditions after planting on shoot growth. 
of days from planting to flowering between them, however, were small after the cold treatment. The growth of non-cold-treated tulips was much retarded in the light, and more than 100 days were needed from planting to anthesis, whereas the cold-treated tulips required about a half of the days. The shoot length was also very short, about $30 \%$ of the light-grown tulips with cold treatment, and there were number of blind bulbs in the plants without cold treatment. Although the shoot growth was also retarded in non-cold-treated tulips grown in the dark, the length was not reduced so much, reaching a final length of about $70 \%$ of that of the cold-treated plants grown either in the light or the dark.

The lengths of individual internodes at flowering are shown in Table 1 and Fig. 2. In cold-treated tulips, total length of the flower stalk was not significantly different under either natural light or dark. The greatest elongation, however, occurred in the last internode in the light, whereas it was observed in the first internode and the elongation of the last internode was markedly inhibited in the dark. The length of the first internode was 2.5 times longer in the dark treatment than in the natural light, and that of the last internode was 4.4 times longer in the light than in the continuous dark treatment. This contrasting pattern of the internodal elongation of cold-treated tulips, however, was not observed in non-cold-treated tulips. Although the last internode was longer than the first internode in the light and the dark stimulated the first internode elongation of the non-cold-treated tulips, the last internode elongation of the non-cold-treated plants was also promoted in the dark as it was observed in the light in the cold-treated plants. The distribution pattern of the ratios of each internode length to the total length of dark-grown tulips without cold treatment seemed to be more similar to that of the light-grown tulips than that of the dark-grown plants both with cold treatment.

The failure of red pigmentation in distal areas of the perianth occurred in the non-cold-treated plants both in the light and the dark (Fig. 2).

The dark treatment given to the light-grown tulips with cold treatment on December 6 promoted the elongation of the first internode, whereas the treatment on December 26 did not (Fig. 3). Elongation of the last internode was not inhibited by the

Table 1. Effects of storage temperatures of bulbs and darkness on length of internodes at flowering.

\begin{tabular}{|c|c|c|c|c|c|c|c|}
\hline \multirow{2}{*}{$\begin{array}{l}\text { Storage } \\
\text { tempera- } \\
\text { ture }\left({ }^{\circ} \mathrm{C}\right)\end{array}$} & \multirow{2}{*}{$\begin{array}{l}\text { Light } \\
\text { regime }\end{array}$} & \multicolumn{6}{|c|}{ Length of internodes $(\mathrm{cm})$} \\
\hline & & $1 \mathrm{st}$ & 2nd & $3 \mathrm{rd}$ & 4 th & 5 th & Total \\
\hline \multirow[t]{3}{*}{$15 / 5^{*}$} & Light & $\begin{array}{c}5.7 \mathrm{~b} \\
(13.9) * *\end{array}$ & $\begin{array}{l}3.1 \mathrm{~b} \\
(7.5)\end{array}$ & $\begin{array}{r}6.5 \mathrm{c} \\
(15.8)\end{array}$ & $\begin{array}{c}5.7 \mathrm{c} \\
(13.9)\end{array}$ & $\begin{array}{l}20.1 \mathrm{~d} \\
(48.9)\end{array}$ & $\begin{array}{l}41.1 d \\
(100)\end{array}$ \\
\hline & \multirow{2}{*}{ Dark } & $18.0 \mathrm{c}$ & $6.2 \mathrm{C}$ & $6.4 \mathrm{c}$ & $3.4 \mathrm{~b}$ & $3.4 \mathrm{a}$ & $37.4 \mathrm{c}$ \\
\hline & & $(48.1)$ & $(16.6)$ & $(17.1)$ & $(9.1)$ & $(9.1)$ & (100) \\
\hline \multirow[t]{4}{*}{20} & \multirow[t]{2}{*}{ Light } & $1.5 \mathrm{a}$ & $0.7 a$ & $0.9 \mathrm{a}$ & $1.0 \mathrm{a}$ & $5.2 \mathrm{~b}$ & $9.3 \mathrm{a}$ \\
\hline & & $(16.1)$ & $(7.5)$ & $(9.7)$ & $(10.8)$ & $(55.9)$ & $(100)$ \\
\hline & \multirow[t]{2}{*}{ Dark } & $6.4 \mathrm{~b}$ & $3.4 \mathrm{~b}$ & $4.6 \mathrm{~b}$ & $3.1 b$ & $10.2 \mathrm{c}$ & $27.7 \mathrm{~b}$ \\
\hline & & $(23.1)$ & $(12.3)$ & $(16.6)$ & $(11.2)$ & $(36.8)$ & $(100)$ \\
\hline
\end{tabular}

*Bulbs were stored at $15^{\circ} \mathrm{C}$ for 20 days and then stored at $5^{\circ} \mathrm{C}$ for 50 days. **Numerals in parentheses are percentage of total length. Values within a column followed by different letters are significantly different at 5\% level according to Duncan's new multiple range test. 

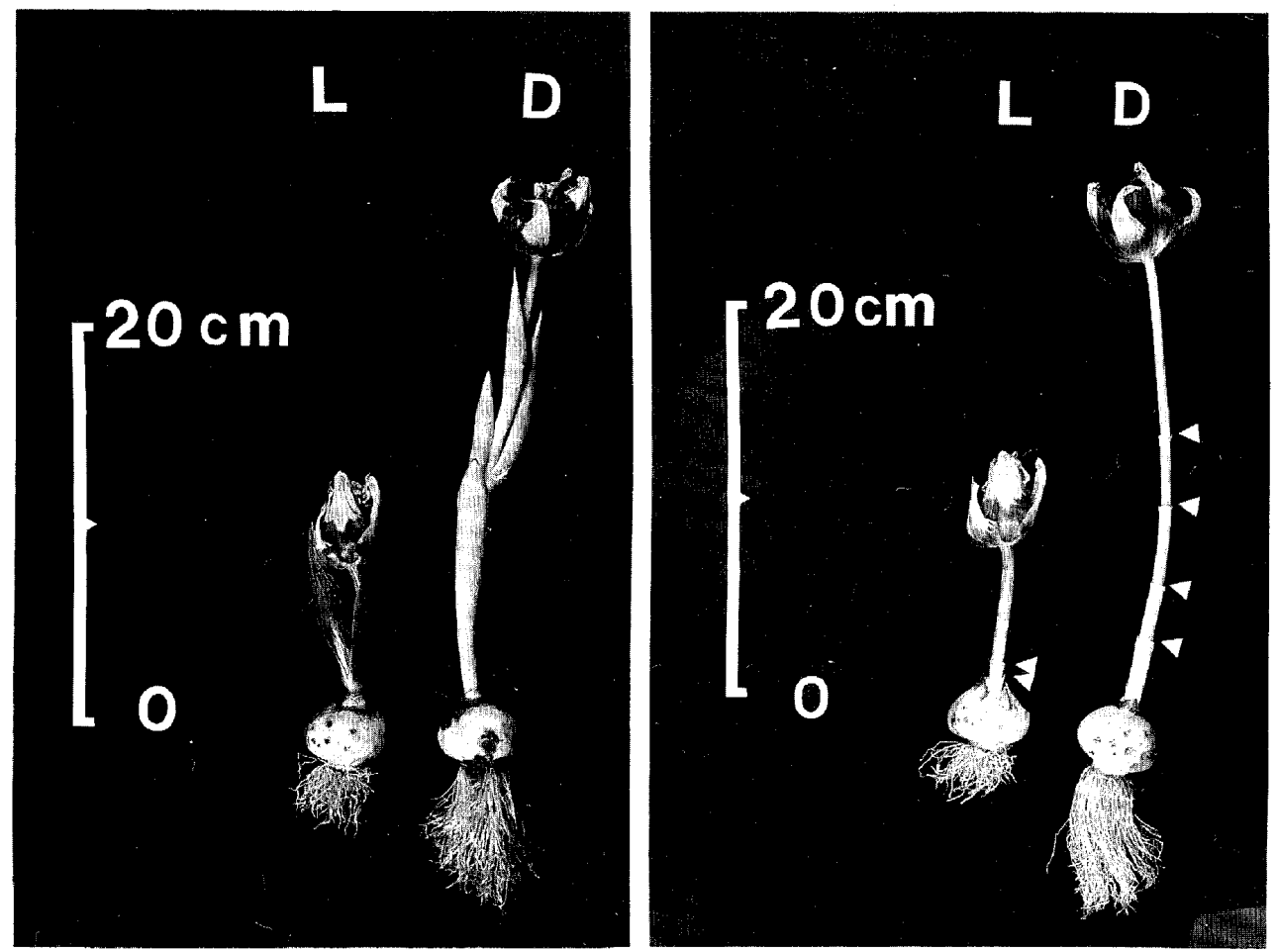

Fig. 2. Growth of internodes of non-cold-treated bulbs grown under natural light (L) and dark (D). Arrows indicate the nodes after removal of the leaves.

dark treatment given on December 6, whereas it was promoted by the treatment on December 26. Light treatment both on December 6 and 26 to the dark-grown tulips did not give any promotive effect on the first internode elongation. A little promotive effect of the light treatment on the last internode elongation was observed when the treatment was given on December 6 but not after flowering.

\section{DISCUSSION}

Our results that the rapid shoot growth and an earlier flowering of cold-treated tulips and that a marked reduction of the stem length and delayed flowering of non-cold-treated tulips under natural light are in accordance with the results of earlier investigations (Rees, 1969 ; Moe and Wickstrsm, 1973, 1979). Growth behavior of individual internodes of cold-treated tulips both in the light and the dark was also in agreement with our previous results (Okubo and Uemoto, 1984). We also obtained the similar results in 'Apeldoorn' (unpublished). Stimulated growth of non-cold-treated tulips in the dark and the similarity of the ratios of each internode length in the dark without cold treatment to those in the light with cold treatment may indicate that darkness partly substitutes for cold requirement of the bulbs. It may be explained by 


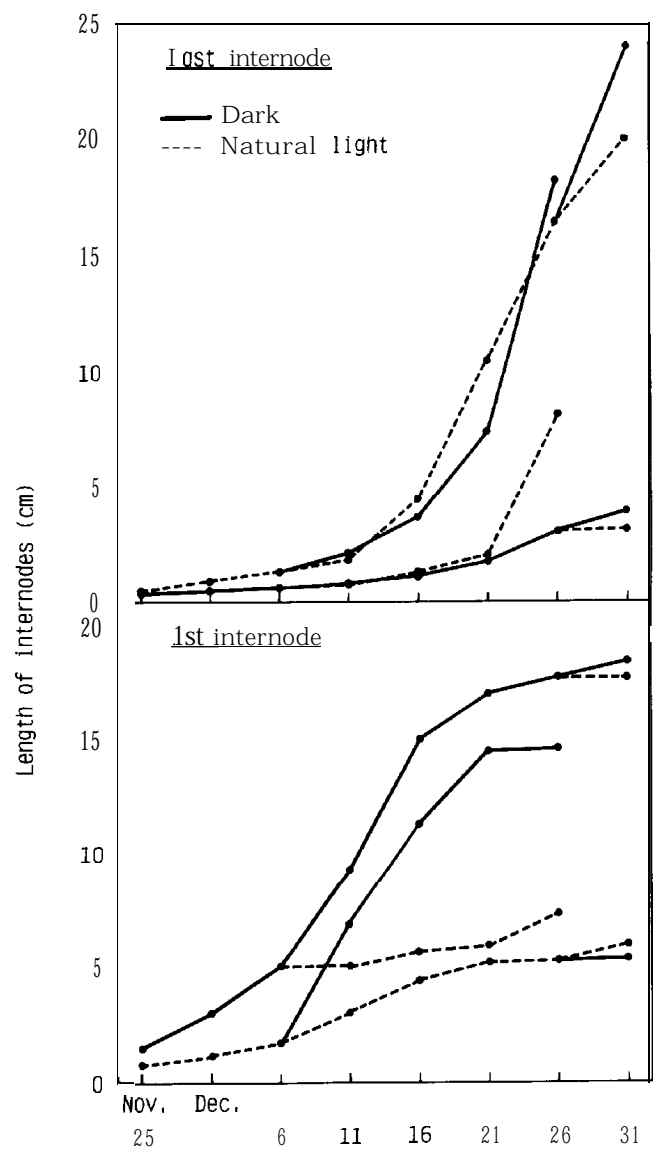

Fig. 3. Effects of dark and light treatments on elongation of the first and the last internodes.

the facts that the amount of endogenous gibberellins increased during cold treatment of tulip bulbs (Aung and De Hertogh, 1967, 1968), that gibberellins partly substituted for the effect of cold treatment (van Bragt and Zijlstra, 1971; van Bragt and van Ast, 1976) and that endogenous gibberellins in tulip plants increased after dark treatment which enhanced the growth (Okubo and Uemoto, 1985). Our results of the dark treatment that the first internode of the non-cold-treated tulips less elongated than that of the cold-treated plants and that the last internode elongation of the plants without cold treatment was more promoted than those with cold treatment may indicate that elongation of the first internode is more dependent on cold treatment than that of upper internodes as Charles-Edwards and Rees (1975) demonstrated. It is also proved that darkness is not only effective on first internode elongation but also on the elongation of the last internode to the plants without cold treatment. Effect of darkness on internode elongation of tulip seems to have close relationship with 
temperature.

It is evident that the last internode elongation of cold-treated tulips is not inhibited or is promoted by the dark if the light is given previously during their growth. Dark treatment given to the light-grown tulips with cold treatment seems to affect the elongation of both the first and the last internodes if it was given when they were in rapid growth.

Saniewski (personal communication, 1989) obtained different results of internode elongation in 'Gudoshnik' affected by dark from ours. We agree to Saniewski's suggestion (personal communication, 1989) that the inhibitory effect of darkness on the elongation of the last internode in our experiments could be caused by earlier and almost total utilization of storage materials from the bulb for greater growth of the lower internodes, whereas in Saniewski's experiment with 'Gudoshnik', darkness stimulated the last internode elongation in smaller degree and, finally, there was enough storage materials in the bulb for the last internode growth. Our measurement ended at or 5 days after flowering, but we also observed sometimes the promotive effect of the darkness on elongation of the last internode 10 days after flowering in 'Paul Richter' only when the plants could survive for long after flowering (unpublished). Total darkness is expected to give a promoting effect also to the last internode.

Cultivar difference to cold requirement should also be considered. Storage temperature and its duration, or the growth temperature may affect differently the growth behavior of internodes of different cultivars. It took only 29 days from planting to flowering in 'Gudoshnik' after a long period (128 days) of $5^{\circ} \mathrm{C}$-treatment (Saniewski, personal communication, 1989), while 46 days were required until flowering in our experiments in 'Paul Richter' after the treatment at $15^{\circ} \mathrm{C}$ for 20 days followed by the $5^{\circ} \mathrm{C}$-treatment for 50 days.

\section{REFERENCES}

Aung, L. H. and A. A. De Hertogh 1967 The occurrence of gibberellin-like substances in tulip bulbs (Tulipa sp. ). Plant \& Cell Physiol., $8: 201-205$

Aung, L. H. and A. A. De Hertogh 1968 Gibberellin-like substances in non-cold and cold treated tulip bulbs (Tulipa sp. ). In "Biochemistry and Physiology of Plant Growth Substances", ed. by F. Wightman and G. Setterfield, Runge Press, Ottawa, pp. 943-956

Charles-Edwards, D. A. and A. R. Rees 1975 An analysis of the growth of forced tulips. 2. Effects of low-temperature treatments during development on plant structure at anthesis. Scientia Hortic.,3:373-381

Moe, R. and A. Wickstrom 1973 The effect of storage temperature on shoot growth, flowering, and carbohydrate metabolism in tulip bulbs. Physiol. Plant., $28: 81-87$

$\mathrm{M}$ oe, R. and A. Wickstrom 1979 Effect of precooling at 5 or $-1^{\circ} \mathrm{C}$ on shoot growth, flowering and carbohydrate metabolism in tulip bulbs. Scientia Hortic., 10: 187-201

Okubo, H. and S. Uemoto 1984 Effects of darkness on stem elongation in tulip. Scientia Hortic., 23 : 391-397

Okubo, H. and S. Uemoto 1985 Changes in endogenous gibberellin and auxin activities during first internode elongation in tulip flower stalk. Plant \& Cell Physiol., $26: 709-719$

Rees, A. R. 1969 Effects of duration of cold treatment on the subsequent flowering of tulips. $J$. hort.Sci., 44 : 27-36 
van Bragt, J. and F. A. Zijlstra 1971 Effects of gibberellins on flowering of tulip cv. "Apeldoorn". Z.Pflanzenphysiol., 64: 139-144

van Bragt, J. and K. J. van Ast 1976 Substitution of the cold requirement on tulip cv. 'Apeldoorn' by GA,. Scientia Hortic., $4: 117-122$ 